\title{
Perspectives in the Management of Ovarian Cancer
}

\author{
MICHAEL A BOOKMAN
}

During the last 30 years, more than 20 thousand women from around the globe have participated in randomized trials that have contributed to our understanding of ovarian cancer biology and helped to define optimal treatment strategies. However, prospective randomized trials are not always perfectly designed, or flawlessly executed, and their definitive results only become available several years after activation. As such, emerging data need to be interpreted, and re-interpreted, within an evolving paradigm of biology, disease management, and clinical resources. In addition, not all important questions are feasible to address using prospective randomized trials, and we have traditionally accepted some inferences that emanate from subset analysis, non-randomized trials, historical controls, retrospective data, and consensus panels.

Progress has generally been incremental, and slower than we appreciate. The role of cytoreductive surgery and platinum-based chemotherapy seems clear. In addition, it is generally accepted, but not universally established, that taxanes should be integrated with primary therapy. There continues to be substantial debate regarding the merits of intraperitoneal therapy, in view of excessive nonhematologic toxicity, lack of data with optimal control arms, and the potential impact of weekly taxane administration in the context of published studies with intraperitoneal therapy. In spite of some initial enthusiasm, none of the randomized trials addressing maintenance or consolidation have achieved meaningful improvements in clinical outcomes. Incorporation of a third cytotoxic agent, in spite of compelling preclinical rationale, and interesting clinical data, has not demonstrated any improvement in time to progression or

Director, Office of Educational Resources, International Gynecologic Cancer Society (http://www.igcs.org), Vice President, Ambulatory Care and Clinical Research, Fox Chase Cancer Center, Philadelphia PA, USA michael.bookman@fccc.edu overall survival when evaluated in several international randomized phase III trials (see figure). Although this particular hypothesis was not validated, a successful collaboration of international cooperative groups developed through the Gynecologic Cancer InterGroup (GCIG), which has helped to share information,

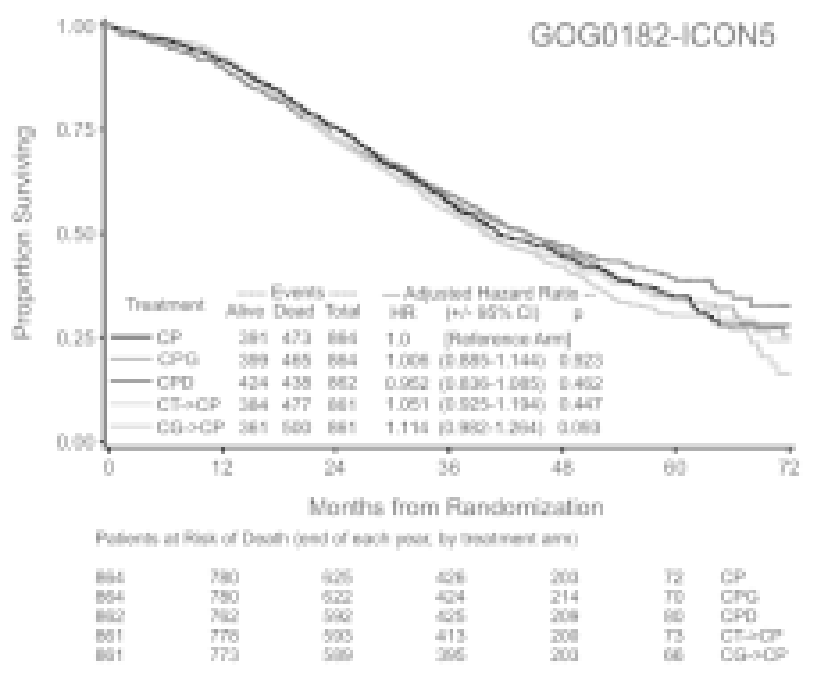

guiding the development of ongoing and future trials.

Attention has appropriately shifted to newer cytotoxic agents, molecular targeted therapeutics, and immunologic strategies. Encouraging data has emerged with inhibition of VEGF, primarily with the use of bevacizumab, and this has prompted several large randomized trials, with the first interim analysis of progression-free survival anticipated in late 2009 (GOG0218). The number and diversity of new agents has challenged our classic clinical trials paradigm, and we need to consider new strategies to efficiently evaluate new agents and combinations. We also need to develop better mechanisms for collaboration among pharmaceutical sponsors, as smaller companies bring innovative ideas forward. 
This presentation will focus on how we have arrived at key management decisions (with or without consensus) related to therapy of ovarian cancer, as well as questions that remain to be resolved. Disease management has been guided not only by phase III trials, but from knowledge of cancer biology, including trials conducted in the setting of recurrent disease or maintenance. Together, this knowledge has influenced surgical guidelines and choice of primary chemotherapy, both in the setting of clinical trials and standard care.

The table below summarizes many of the key biologic and historical observations that have an impact on the management of ovarian cancer, together with references related to ovarian cancer.

\begin{tabular}{|c|c|c|}
\hline \multicolumn{3}{|c|}{ BIOLOGIC OBSERVATIONS } \\
\hline Type I/II Tumours & $\begin{array}{l}\text { Definition of clinical and molecular } \\
\text { characteristics to differentiate low-grade } \\
\text { and borderline tumours (Type I) from high } \\
\text { grade serous tumours (Type II). }\end{array}$ & $\begin{array}{l}\text { Distinct origin of LMP and high-grade tumours has been verified, } \\
\text { reinforcing clinical management strategies [1] [2]. Emphasizes need } \\
\text { or controlled trials to evaluate treatment options for recurrent low } \\
\text { fgrade tumours. }\end{array}$ \\
\hline Early-Stage Disease & $\begin{array}{l}\text { Understanding clinical features and risk } \\
\text { factors associated with early-stage disease }\end{array}$ & $\begin{array}{l}\text { Recognition of distinct distribution of histologic subtypes in early-stage } \\
\text { disease; importance of complete surgical staging: EORTC-ACTION [3] } \\
\text { [4]; risk of recurrence associated with high-grade serous histology } \\
\text { and/or positive peritoneal cytology; clarification of risk associated with } \\
\text { well-staged clear cell tumours; potential for survival impact of adjuvant } \\
\text { therapy in high-risk serous tumours: GOG [5] }\end{array}$ \\
\hline Advanced-Stage Disease & Analysis of prognostic factors & $\begin{array}{l}\text { Verification that mucinous tumours are poorly-responsive to platinum } \\
\text { based herapy with inferior long-term clinical outcomes: UK [6], GOG } \\
\text { [7], and that age is a negative prognostic factor }\end{array}$ \\
\hline Stem Cell Hypothesis & $\begin{array}{l}\text { Existence of treatment-resistant } \\
\text { regenerative subpopulations within a } \\
\text { treatment-sensitive tumour }\end{array}$ & $\begin{array}{l}\text { Recognition of the limitations associated with platinum-based primary } \\
\text { therapy and the need to explore alternatives guided by molecular and } \\
\text { genomic analysis [8] [9] }\end{array}$ \\
\hline $\begin{array}{l}\text { Epithelial- } \\
\text { Mesenchymal Transition }\end{array}$ & $\begin{array}{l}\text { Characterization of markers associated with } \\
\text { transition from epithelial to high-grade } \\
\text { invasive mesenchymal phenotype }\end{array}$ & $\begin{array}{l}\text { Molecular basis for carcinosarcoma and high-grade epithelial } \\
\text { malignancies, activation (and targeting) of SRC-associated pathways } \\
\text { [64] }\end{array}$ \\
\hline $\begin{array}{l}\text { Synthetic Lethal } \\
\text { Paradigms }\end{array}$ & $\begin{array}{l}\text { Genetic and epigenetic silencing of } \\
\text { pathways involved in DNA repair }\end{array}$ & $\begin{array}{l}\text { Opportunity to exploit synthetic lethality using PARP inhibition }(+/- \\
\text { chemotherapy) in tumours with loss of BRCA function [10] [11]; } \\
\text { epigenetic silencing of BRCA [12] [13]; recognition of secondary } \\
\text { mutations in BRCA associated with platinum resistance [14] [15] }\end{array}$ \\
\hline \multicolumn{3}{|c|}{ SURGICAL INTERVENTIONS } \\
\hline & Extent of cytoreductive surgery & $\begin{array}{l}\text { Extent of post-operative residual disease clearly correlates with } \\
\text { outcome [16], but the requirement for cytoreductive surgery has not } \\
\text { been validated in a randomized trial. Multiple retrospective studies } \\
\text { confirm that women who undergo "maximum" cytoreductive surgery } \\
\text { will have improved median survival [17] [18], but the degree of surgical } \\
\text { effort has not been validated in a prospective randomized trial. As } \\
\text { such, the relative impact of tumour biology vssurgical skill remains } \\
\text { unresolved. }\end{array}$ \\
\hline \multirow[t]{2}{*}{$\begin{array}{l}\text { Surgical } \\
\text { Interventions }\end{array}$} & Timing of cytoreductive surgery & $\begin{array}{l}\text { Interval cytoreduction is superior to no cytoreduction: EORTC [19]; } \\
\text { initial cytoreduction followed by interval cytoreduction in appropriate } \\
\text { patients is equivalent to initial cytoreduction alone: GOG0152 [20] } \\
\text { [21]. } \\
\text { For patients with advanced IIIC-IV disease, neoadjuvant } \\
\text { chemotherapy with interval cytoreduction achieves equivalent surviva } \\
\text { to initial cytoreduction, with improved safety (EORTC-NCIC Phase III) } \\
\text { [IGCS] }\end{array}$ \\
\hline & Role of secondary surgical assessment & $\begin{array}{l}\text { Secondary surgical assessment for patients in clinical } \\
\text { complete remission will provide prognostic information, } \\
\text { but surgery has not been shown to have an impact on } \\
\text { survival or optimization of secondary treatment: } \\
\text { GOG0158 [22] }\end{array}$ \\
\hline
\end{tabular}




\begin{tabular}{|c|c|c|}
\hline \multicolumn{3}{|c|}{ CHEMOTHERAPY AND MOLECULAR TARGETED INTERVENTIONS } \\
\hline \multirow[t]{5}{*}{ Platinum Agents } & Cisplatin vs Carboplatin & $\begin{array}{l}\text { Carboplatin associated with equivalent long-term } \\
\text { outcomes, reduced non-hematologic toxicity, increased } \\
\text { hematologic toxicity: SWOG [23], GOG [24], AGO [25]. }\end{array}$ \\
\hline & Platinum dose intensity & $\begin{array}{l}\text { No evidence of improved long-term outcomes within } \\
\text { ranges achievedusing conventional therapy or hemato- } \\
\text { poietic progenitor cell support: DCOG [26], LGOG [27] }\end{array}$ \\
\hline & Dose intensity and infusion duration & $\begin{array}{l}\text { Infusion duration correlates closely with hematologic } \\
\text { toxicity, but not efficacy. No evidence for dose-response } \\
\text { relationship within usualclinical dose ranges: NCIC- } \\
\text { EORTC [28], GOG [29] [30] [31] }\end{array}$ \\
\hline & Incorporation in primary therapy & $\begin{array}{l}\text { Improved median survival with incorporation of } \\
\text { paclitaxel: GOG111 [32], OV10 [33] [34]. }\end{array}$ \\
\hline & Weekly therapy & $\begin{array}{l}\text { Improved therapeutic ratio (phase I-II): MSKCC [35], } \\
\text { GOG [36] and improved progression-free survival (phase } \\
\text { III): JGOG [37] associated with weekly therapy . }\end{array}$ \\
\hline \multirow[t]{3}{*}{ Taxanes } & Alternative agents & $\begin{array}{l}\text { Docetaxel associated with different toxicity profile, but } \\
\text { withoutimproved long-term outcomes: SCOTROC [38]. } \\
\text { Epothilones havesimilar activity with different toxicity } \\
\text { profiles. Tubulin â-III isoformsemerging as predictors of } \\
\text { resistance [65] [66] [67]. }\end{array}$ \\
\hline & Intraperitoneal cisplatin & $\begin{array}{l}\text { Improved survival validated in phase III trials, but with } \\
\text { increased toxicity GOG0104 [39], GOG0114 [40], } \\
\text { GOG0172 [41], Meta-analysis [42] [43], Commentary [44] } \\
\text { [45] }\end{array}$ \\
\hline & Intraperitoneal carboplatin & $\begin{array}{l}\text { Reduction in toxicity, but activated more slowly, com- } \\
\text { pared to cisplatin. Awaiting randomized trials for } \\
\text { validation }\end{array}$ \\
\hline $\begin{array}{l}\text { Intraperitoneal } \\
\text { Therapy }\end{array}$ & Intraperitoneal paclitaxel & $\begin{array}{l}\text { Incorp.orated in phase III program, but importance } \\
\text { nclear } \\
\text { [41] }\end{array}$ \\
\hline $\begin{array}{l}\text { Incorporation of } \\
\text { Additional Cytotoxic } \\
\text { Agents }\end{array}$ & $\begin{array}{l}\text { Gemcitabine, epirubicin, PEG-liposomal } \\
\text { doxorubicin, topotecan }\end{array}$ & $\begin{array}{l}\text { Extensively evaluated through international phase III } \\
\text { trials involving } \\
\text { multiple GCIG members. No evidence for improved } \\
\text { progression-free or overall survival with any new } \\
\text { regimen: AGO-GINECO (epirubicin) [46], NSGO } \\
\text { (epirubicin) [47], AGO (gemcitabine) [IGCS], } \\
\text { NCICEORTC (topotecan) [48], MITO (topotecan) [49], } \\
\text { GOG0182 (multipl e) [50] }\end{array}$ \\
\hline \multirow[t]{5}{*}{$\begin{array}{l}\text { Targeted Cytotoxic } \\
\text { Agents }\end{array}$} & $\begin{array}{l}\text { Antifolates, trabectedin and other } \\
\text { xenobiotics, Aurora Kinase A inhibition, } \\
\text { Kinesin Spindle Protein inhibition }\end{array}$ & $\begin{array}{l}\text { Activity of trabectedin in platinum-sensitive recurrent } \\
\text { disease [77]. Limited activity in platinum-resistant } \\
\text { disease (except for pemetrexed) [78] [79] }\end{array}$ \\
\hline & $\begin{array}{l}\text { VEGF, VEGFR, angiopoietin-2, HIF1á, } \\
\text { VEGFR-TKI }\end{array}$ & $\begin{array}{l}\text { Positive phase II data with Bevacizumab anti-VEGF } \\
\text { antibody: GOG[51], Industry Phase II [52], followed by } \\
\text { phase III front-line trials (GOG0218, OV7) in combination }\end{array}$ \\
\hline & & $\begin{array}{l}\text { Limited activity with Aflibercept VEGF-trap single } \\
\text { agent }\end{array}$ \\
\hline & & $\begin{array}{l}\text { Activity with VEGFR-TKI Phase II: Pazopanib [80] and } \\
\text { Cediranib [81], followed by phase III trials in small- } \\
\text { volume disease (in progress) }\end{array}$ \\
\hline & & $\begin{array}{l}\text { Potential increased response rate with combinations of } \\
\text { anti-VEGF and VEGFR-TKI (sorafenib), but with } \\
\text { increased toxicity [76]. Most combinations unexplored }\end{array}$ \\
\hline
\end{tabular}




\begin{tabular}{|c|c|c|}
\hline $\begin{array}{l}\text { Molecular Targeted } \\
\text { Agents }\end{array}$ & $\begin{array}{l}\text { IGFR1, FGF, HGF, Integrins } \\
\text { MAPK, MEK, ERK, SRC } \\
\text { TRAIL, IAP } \\
\text { Notch, Hedgehog }\end{array}$ & $\begin{array}{l}\text { Cetuximab (anti-EGFR) single-agent and in combination } \\
\text { withchemotherapy [68], limited activity. Herceptin (anti- } \\
\text { HER2) single-agentin HER2-positive tumours, limited ac- } \\
\text { tivity [69]. Pertuzumab (anti-HER2) single agent, limited } \\
\text { activity [70], relationship to HER3expression [71]. } \\
\text { Gefitinib (EGFR TKI) single agent [72], activity limited } \\
\text { to receptor mutations [73]. Erlotinib limited activity [74]. } \\
\text { Lapatinib (dual TKI) single agent, limited activity. } \\
\text { Antibody-based strategies under evaluatio } \\
\text { (TKI) TKI-based strategies under evaluation } \\
\text { Early studies in progress } \\
\text { Early studies in progress }\end{array}$ \\
\hline \multicolumn{3}{|c|}{ MAINTENANCE OR CONSOLIDATION } \\
\hline $\begin{array}{l}\text { Maintenance with } \\
\text { Cytotoxic Agents }\end{array}$ & $\begin{array}{l}\text { Evaluated with interferon-alpha, 90Y-anti- } \\
\text { HMFG1 antibody, murine anti-CA125 }\end{array}$ & $\begin{array}{l}\text { paclitaxel, IP platinumNo improvement in survival } \\
\text { from completed trials: Epirubicin [53] Topotecan [54] } \\
\text { [55], Paclitaxel [56], IP Platinum [57]. Trial in progress } \\
\text { with paclitaxel and polyglutamated paclitaxel } \\
\text { (GOG0212) } \\
\text { No improvement in survival from completed trials: 90Y. } \\
\text { anti-HMFG1 [58], Oregovomab [59], Interferon-á [60]. } \\
\text { Trials in progress with other antibodies, bevacizumab, and } \\
\text { VEGFR-TKI. }\end{array}$ \\
\hline \multicolumn{3}{|c|}{ REGULATION OF THE IMMUNE RESPONSE } \\
\hline $\begin{array}{l}\text { Immunologic } \\
\text { Factors and } \\
\text { Interventions }\end{array}$ & $\begin{array}{l}\text { Cytokines } \\
\text { Antibody-Based Interventions } \\
\text { Intratumoural T lymphocytes }\end{array}$ & $\begin{array}{l}\text { Interferon-ã-1b: Phase III evaluation in combination with } \\
\text { chemotherapy, no improvement in survival [61] } \\
\text { Oregovomab (murine anti-CA125): Phase III maintenance, } \\
\text { noimprovement in survival, but identification of favorable } \\
\text { subpopulationbased on generation of an immune response, sug- } \\
\text { gesting that regulation of the immune response could have an } \\
\text { impact in the settingof established disease [59]. Abagovomab } \\
\text { (murine anti-idiotype CA125) studies in progress [75]. } \\
\text { Improved survival associated with higher number of tumour in- } \\
\text { filtrating lymphocytes [62] and lower ratios of mmunoregulatory } \\
\text { T lymphocytes [63] } \\
\text { Autologous, peptide-based, and dendritic cell strategies under } \\
\text { evaluation }\end{array}$ \\
\hline
\end{tabular}

\section{REFERENCES:}

1. Singer $G$, Stöhr $R$, Cope L, et al. Patterns of p53 mutations separate ovarian serous borderline tumours and low- and high-grade carcinomas and provide support for a new model of ovarian carcinogenesis: a mutational analysis with immunohistochemical correlation. Am J Surg Pathol 2005;29:218-24

2. Pohl G, Ho CL, Kurman RJ, et al. Inactivation of the mitogen-activated protein kinase pathway as a potential target-based therapy in ovarian serous tumours with KRAS or BRAF mutations. Cancer Res 2005;65:1994-2000.
3. International Collaborative Ovarian Neoplasm 1 (ICON1) and European Organisation for Research and Treatment of Cancer Collaborators-Adjuvant ChemoTherapy In Ovarian Neoplasm (EORTC-ACTION). International Collaborative Ovarian Neoplasm Trial and Adjuvant ChemoTherapy In Ovarian Neoplasm Trial: Two Parallel Randomized Phase III Trials of Adjuvant Chemotherapy in Patients With Early-Stage Ovarian Carcinoma. J Natl Cancer Inst, 2003;95:105-12. 
4. Trimbos JB, Vergote I, Bolis $G$, et al. For the EORTC ACTION collaborators. Impact of Adjuvant Chemotherapy and Surgical Staging in Early-Stage Ovarian Carcinoma: European Organisation for Research and Treatment of Cancer-Adjuvant ChemoTherapy in Ovarian Neoplasm Trial. J Natl Cancer Inst 2003;95:113-25

5. Chan JK, Tian C, et al. Prognostic factors for high-risk early-stage epithelial ovarian cancer. A Gynecologic Oncology Group study. Cancer 2008;112:2202-10.

6. Hess V, A'Hern R, Nasiri N, et al. Mucinous epithelial ovarian cancer: a separate entity requiring specific treatment. J Clin Oncol 2004;22:1040-4.

7. inter WE 3rd, Maxwell GL, Tian C, et al. Prognostic factors for stage III epithelial ovarian cancer: a Gynecologic Oncology Group Study. J Clin Oncol 2007; 25:3621-7.

8. Szotek PP, Pieretti-Vanmarcke R, Masiakos PT, et al. Ovarian cancer side population defines cells with stem cell-like characteristics and Mullerian Inhibiting Substance responsiveness. Proc Natl Acad Sci U S A. 2006;103:11154-9.

9. Glinsky GV. "Stemness" genomics law governs clinical behavior of human cancer: implications for decision making in disease management. J Clin Oncol 2008;26:2846-53.

10. McCabe N, Lord CJ, Tutt AN, etal. BRCA2-deficient CAPAN1 cells are extremely sensitive to the inhibition of Poly (ADP-Ribose) polymerase: an issue of potency. Cancer Biol Ther. 2005;4:934-6.

11. Bryant HE, Schultz N, Thomas HD, et al. Specific killing of $B R C A 2$ - deficient tumours with inhibitors of poly(ADP. ribose) polymerase. Nature 2005;434:913-7.

12. Esteller M, Silva JM, Dominguez G, et al. Promoter hypermethylation and BRCA1 inactivation in sporadic breast and ovarian tumours. J Nat1 Cancer Inst 2000;92:5649 .

13. Hilton JL, Geisler JP, Rathe JA, et al. Inactivation of BRCA1 and BRCA2 in ovarian cancer. $J$ Natl Cancer Inst 2002;94:1396-406.

14. Edwards SL, Brough R, Lord CJ, Resistance to therapy caused by intragenic deletion in BRCA2. Nature 2008;451:1111-5.

15. Sakai W, Swisher EM, Karlan BY, et al. Secondary mutations as a mechanism of cisplatin resistance in BRCA2mutated cancers. Nature 2008;451:1116-20.

16. Winter WE 3rd, Maxwell GL, Tian C, etal. Tumour residual after surgical cytoreduction in prediction of clinical outcome in stage IV epithelial ovarian cancer: a Gynecologic Oncology Group Study. J Clin Oncol 2008;26:83-9.

17. Eisenkop SM, Spirtos NM, Lin WC. "Optimal" cytoreduction for advanced epithelial ovarian cancer: a commentary. Gynecol Oncol 2006;103:329-35.

18. Dowdy SC, Loewen RT, Aletti G, Feitoza SS, Cliby W. As sessment of outcomes and morbidity following diaphragmatic peritonectomy for women with ovarian carcinoma. Gynecol Oncol 2008;109:303-7.

19. van der Burg $M E$, van Lent $M$, Buyse $M$, et al. The effect of debulking surgery after induction chemotherapy on the prognosis in advanced epithelial ovarian cancer. Gynecological Cancer Cooperative Group of the European Organization for Research and Treatment of Cancer. $N$ Engl $J$ Med 1995;332:629-34.
20. Rose $P G$, Nerenstone $S$, Brady $M F$, et al. Secondary surgical cytoreduction for advanced ovarian carcinoma. N EngI J Med 2004;351:2489-97.

21. Bristow RE, Eisenhauer EL, Santillan A, Chi DS. Delaying the rimary surgical effort for advanced ovarian cancer: a systematic review of neoadjuvant chemotherapy and interval cytoreduction. Gynecol Oncol 2007;104:480-90.

22. Greer BE, Bundy BN, Ozols RF, et al. Implications of second-look laparotomy in the context of optimally resected stage III ovarian cancer: a non-randomized comparison using an explanatory analysis: a Gynecologic Oncology Group study. Gynecol Oncol 2005;99:71-9.

23. Alberts DS, Green $S$, Hannigan $E V$, et al. Improved therapeutic index of carboplatin plus cyclophosphamide versus cisplatin plus cyclophosphamide: final report by the Southwest Oncology Group of a phase III randomized trial in stages III and IV ovarian cancer. J Clin Oncol 1992;10:70617.

24. Ozols RF, Bundy BN, Greer BE, et al. Phase III trial of carboplatin and paclitaxel compared with cisplatin and paclitaxel in patients with optimally resected stage III ovarian cancer: a Gynecologic Oncology Group study. J Clin Oncol 2003;21:3194-200.

25. du Bois A, Luck HJ, Meier W, et al. Arbeitsgemeinschaft Gynakologische Onkologie Ovarian Cancer Study Group. A randomized clinical trial of cisplatin/paclitaxel versus carboplatin/paclitaxel as first-line treatment of ovarian cancer. J Natl Cancer Inst 2003;95:1320-9

26. Jakobsen A, Bertelsen K, Andersen JE, et al. Dose-effect study of carboplatin in ovarian cancer: a Danish Ovarian Cancer Group study. J Clin Oncol. 1997;15:193-8.

27. Gore M, Mainwaring P, A'Hern R, et al. Randomized trial of dose-intensity with single-agent carboplatin in patients with epithelial ovarian cancer. London Gynaecological Oncology Group. J Clin Oncol. 1998;16:2426-34.

28. Eisenhauer EA, ten Bokkel Huinink WW, Swenerton KD, et al: European- Canadian randomized trial of paclitaxel in relapsed ovarian cancer: igh-dose versus low-dose and long versus short infusion. J Clin Oncol 12:2654-66, 1994

29. Omura GA, Brady MF, Look KY, et al. Phase III trial of paclitaxel at two dose levels, the higher dose accompanied by filgrastim at two dose levels in platinum-pretreated epithelial ovarian cancer: an intergroup study. J Clin Oncol 2003;21:2843-8.

30. Bolis $G$, Scarfone $G$, Polverino $G$, Raspagliesi $F$, et al. Paclitaxel 175 or $225 \mathrm{mg}$ per meters squared with carboplatin in advanced ovarian cancer: a randomized trial. J Clin Oncol 2004;22:686-90.

31. Markman $M$, Rose PG, Jones E, et al: Ninety-six-hour infusional paclitaxel as salvage therapy of ovarian cancer patients previously failing treatment with 3-hour or 24hour paclitaxel infusion regimens. J Clin Oncol 16:1849- 51, 1998

32. McGuire WP, Hoskins WJ, Brady MF, et al. Cyclophosphamide and cisplatin compared with paclitaxel and cisplatin in patients with stage III and stage IV ovarian cancer. $N$ Engl J Med 1996;334:1-6.

33. Piccart $M J$, Bertelsen $K$, James $K$, et al. Randomized intergroup trial of cisplatin-paclitaxel versus cisplatin-cyclophosphamide in women with advanced epithelial ovarian cancer: three-year results. J Natl Cancer Inst 2000:92:699708 . 
34. Piccart MJ, Bertelsen K, Stuart G, et al. Long-term followup confirms a survival advantage of the paclitaxel-cisplatin regimen over the cyclophosphamide-cisplatin combination in advanced ovarian cancer. Int $J$ Gynecol Cancer 2003;13(Suppl 2):144-8.

35. Fennelly D, Aghajanian C, Shapiro F, et al: Phase I and pharmacologic study of paclitaxel administered weekly in patients with relapsed ovarian cancer. J Clin Oncol 1997;15:187-192.

36. Markman M, Blessing J, Rubin SC, et al. Phase II trial of weekly paclitaxel $(80 \mathrm{mg} / \mathrm{m} 2)$ in platinum and paclitaxelresistant ovarian and primary peritoneal cancers: a Gynecologic Oncology Group study. Gynecol Oncol. 2006;101:43640.

37. Isonishi S, Yasuda M, Takahashi F, etal. Randomized phase III trial ofconventional paclitaxel and carboplatin (c-TC) versus dose dense weekly paclitaxel and carboplatin (dd$T C)$ in women with advanced epithelial ovarian, fallopian tube, or primary peritoneal cancer: Japanese Gynecologic Oncology Group. J Clin Oncol 2008;26:Abstract 5506

38. Vasey PA, Jayson GC, Gordon A, et al. Phase III randomized trial of docetaxel-carboplatin versus paclitaxelcarboplatin as first-line chemotherapy for ovarian carcinoma. J Natl Cancer Inst 2004;96:1682-91.

39. Alberts DS, Liu PY, Hannigan EV, et al: Intraperitoneal cisplatin plus intravenous cyclophosphamide versus intravenous cisplatin plus intravenous cyclophosphamide for stage III ovarian cancer. N Engl J Med 1996;335:1950-5.

40. Markman M, Bundy BN, Alberts DS, et al: Phase III trial of standard-dose intravenous cisplatin plus paclitaxel versus moderately high-dose carboplatin followed by intravenous paclitaxel and intraperitoneal cisplatin in smallvolume stage III ovarian carcinoma: An intergroup study of the Gynecologic Oncology Group, Southwestern Oncology Group, and Eastern Cooperative Oncology Group. J Clin Oncol 2001;19:1001-7.

41. Armstrong DK, Bundy B, Wenzel L, et al. Intraperitoneal cisplatin and paclitaxel in ovarian cancer. $N$ Engl J Med 2006;354:34-43.

42. Jaaback $K$, Johnson N. Intraperitoneal chemotherapy for the initial management of primary epithelial ovarian cancer. Cochrane Database Syst Rev 2006;25:CD005340.

43. Hess LM, Benham-Hutchins M, Herzog TJ, et al. A metaanalysis of the efficacy of intraperitoneal cisplatin for the front-line treatment of ovarian cancer. Int J Gynecol Cancer 2007;17:561-70.

44. Swart AM, Burdett S, Ledermann J, Mook P, Parmar MK. Why i.p. therapy cannot yet be considered as a standard of care for the first-line treatment of ovarian cancer: a systematic review. Ann Oncol 2008;19:688-95.

45. Ozols RF, Bookman MA, du Bois A, et al. Intraperitoneal cisplatin therapy in ovarian cancer: comparison with standard intravenous carboplatin and paclitaxel. Gynecol Oncol 2006;103:1-6.

46. du Bois A, Weber B, Rochon J, et al. Addition of epirubicin as a third drug to carboplatin-paclitaxel in first-line treatment of advanced ovarian cancer: a prospectively randomized gynecologic cancer intergroup trial by the Arbeitsgemeinschaft Gynaekologische Onkologie Ovarian Cancer Study Group and the Groupe d'Investigateurs Nationaux pour l'Etude des Cancers Ovariens. J Clin Oncol 2006;24:1127-35.
47. Kristensen GB, Vergote I, Stuart G, et al. First-line treatment of ovarian cancer FIGO stages IIb-IV with paclitaxel/ epirubicin/carboplatin versus paclitaxel/carboplatin. Int J Gynecol Cancer 2003;13 (Suppl 2):172-7.

48. Hoskins PJ, Vergote I, Stuart G, et al. Phase III trial of cisplatin plus topotecan followed by paclitaxel plus carboplatin versus standard carboplatin plus paclitaxel as first-line chemotherapy in women with newly diagnosed advanced epithelial ovarian cancer (EOC) (OV.16). A Gvnecologic Cancer Intergroup Study of the NCIC CTG, EORTC GCG, and GEICO. J Clin Oncol 2008;26:Abstract LBA5505

49. Scarfone $G$, Scambia $G$, Raspagliesi F, et al. A multicenter, randomized, phase III study comparing paclitaxel/ carboplatin (PC) versus topotecan/paclitaxel/carboplatin (TPC) in patients with stage III (residual tumour $>1 \mathrm{~cm}$ after primary surgery) and IV ovarian cancer (OC). J Clin Oncol 2006;24 (Suppl 18S):Abstract 5003.

50. Bookman MA, Brady MF, McGuire W, et al. Evaluation of New Platinum- Based Treatment Regimens in AdvancedStage Ovarian Cancer: a Phase III Trial of the Gynecologic Cancer InterGroup (GCIG). JClin Oncol 2009;27 (epub PMID 19224846).

51. Cannistra SA, Matulonis UA, Penson RT, et al. Phase II study of bevacizumab in patients with platinum-resistant ovarian cancer or peritoneal serous cancer. J Clin Oncol 2007;25:5180-6.

52. Burger RA, Sill MW, Monk BJ, Greer BE, Sorosky JI. Phase II trial of bevacizumab in persistent or recurrent epithelial ovarian cancer or primary peritoneal cancer: a Gynecologic Oncology Group Study. J Clin Oncol 2007;25:516571.

53. Bolis $G$, Danese $S$, Tateo $S$, et al. Epidoxorubicin versus no treatment as consolidation therapy in advanced ovarian cancer: results from a phase II study. Int J Gynecol Cancer 2006; 16 (Suppl 1):74-8.

54. Pfisterer J, Weber B, Reuss A, et al. Randomized phase III trial of topotecan following carboplatin and paclitaxel in first-line treatment of advanced ovarian cancer: a gynecologic cancer intergroup trial of the AGO-OVAR and GINECO. J Nat1 Cancer Inst 2006;98:1036-45.

55. De Placido S, Scanbia G, Di Vagno G, et al. Topotecan compared with no therapy after response to surgery and carboplatin/paclitaxel in patients with ovarian cancer: Multicenter Italian Trials in Ovarian Cancer (MITO-1) randomized study. J Clin ncol 2004;22:2635-2642

56. Markman M, Liu PY, Wilczynski S, et al. Phase III randomized trial of 12 versus 3 months of maintenance paclitaxel in patients with advanced ovarian cancer after complete response to platinum and paclitaxel-based chemotherapy: a Southwest Oncology Group and Gynecologic Oncology Group trial. J Clin Oncol 2003;21:2460-5.

57. Piccart MJ, Floquet A, Scarfone $G$, et al. Intraperitoneal cisplatin versus no further treatment: 8-year results of EORTC 55875, a randomized phase III study in ovarian cancer patients with a pathologically complete remission after platinum-based intravenous chemotherapy. Int $J$ Gynecol Cancer 2003;13 (Suppl 2):196-203.

58. Verheijen RH, Massuger LF, Benigno BB, et al. Phase III trial of intraperitoneal therapy with yttrium-90-labeled HMFG1 murine monoclonal antibody in patients with epithelial ovarian cancer after a surgically defined complete remission. J Clin Oncol 2006;24:571-8. 
59. Berek JS, Taylor PT, Gordon A, et al. Randomized, placebo-controlled study of oregovomab for consolidation of clinical remission in patients with advanced ovarian cancer. J Clin Oncol 2004;22:3507-16.

60. Alberts DS, Hannigan EV, Liu PY, et al. Randomized trial of adjuvant intraperitoneal alpha-interferon in stage III ovarian cancer patients who have no evidence of disease after primary surgery and chemotherapy: An intergroup study. Gynecol Oncol 2006;100:133-8.

61. Alberts DS, Marth C, Alvarez RD, et al. Randomized phase 3 trial of interferon gamma-1b plus standard carboplatin/ paclitaxel versus carboplatin/paclitaxel alone for first-line treatment of advanced ovarian and primary peritoneal carcinomas: results from a prospectively designed analysis of progression-free survival. Gynecol Oncol. 2008;109:174-81.

62. Zhang L, Conejo-Garcia JR, Katsaros D, et al. Intratumoural T cells, recurrence, and survival in epithelial ovarian cancer. $N$ Engl J Med 2003;348:203-13.

63. Curiel TJ, Coukos G, Zou L, et al. Specific recruitment of regulatory $T$ cells in ovarian carcinoma fosters immune privilege and predicts reduced survival. Nat Med 2004;10:942-9.

64. Larue L and Bellacosa A. Epithelial-mesenchymal transition in development and cancer: role of phosphatidylinositol 30 kinase/AKT pathways. Oncogene 2005;24:7443-54.

65. Dumontet C, Jordan MA, Lee FFY. Ixabepilone: targeting BIII-tubulin expression in taxane-resistant malignancies. Mol Cancer Ther 2009;8:17-25.

66. Mozzetti S, Iantomasi R, et al. Molecular Mechanisms of Patupilone Resistance. Cancer Res 2008;68:10197-204.

67. Sève P, Dumontet C. Is class III â-tubulin a predictive factor in patients receiving tubulin-binding agents? Lancet Oncol 2008; 9: 168-75.

68. Alvarez-Secord A, Blessing JA, et al. Phase II trial of cetuximab and carboplatin in relapsed platinum-sensitive ovarian cancer and evaluation of epidermal growth factor receptor expression: A Gynecologic Oncology Group study. Gynecol Oncol 2008;108:493-499.

69. Bookman MA, Darcy KM, Clarke-Pearson D, Boothby RA, Horowitz IR. Evaluation of monoclonal humanized antiHER2 antibody, trastuzumab, in patients with recurrent or refractory ovarian or primary peritoneal carcinoma with overexpression of HER2: A phase II trial of the Gynecologic Oncology Group. J Clin Oncol 2003;21:283-290.
70. Gordon MS, Matei D, et al. Clinical activity of pertuzumab (rhuMAb 2C4), a HER dimerization inhibitor, in advanced ovarian cancer: potential predictive relationship with tumour HER2 activation status. J Clin Oncol 2006;24:4324-32.

71. Tanner B, Hasenclever D, et al. ErbB-3 predicts survival in ovarian cancer. J Clin Oncol 2006;24:4317-23.

72. Posadas EM, Liel MS, et al. A phase II and pharmacodynamic study of gefitinib in patients with refractory or recurrent epithelial ovarian cancer. Cancer 2007;109:132330.

73. Schilder RJ, Sill MW, et al. Phase II study of gefitinib in patients with relapsed or persistent ovarian or primary peritoneal carcinoma and evaluation of epidermal growth factor receptor mutations and immunohistochemical expression: a Gynecologic Oncology Group Study. Clin Cancer Res 2005;11:5539-48.

74. Gordon AN, Finkler N, et al. Efficacy and safety of erlotinib $\mathrm{HCl}$, an epidermal growth factor receptor (HER1/EGFR) tyrosine kinase inhibitor, in patients with advanced ovarian carcinoma: results from a phase II multicenter study. Int J Gynecol Cancer 2005;15:785-92

75. Sabbatini P, Dupont J, et al. Phase I study of abagovomab in patients with epithelial ovarian, fallopian tube, or primary peritoneal cancer. Clin Cancer Res 2006;12:5503-10.

76. Azad NS, Posadas EM, et al. Combination targeted therapy with sorafenib and bevacizumab results in enhanced toxicity and antitumour activity. J Clin Oncol 2008;26:3709-14.

77. Krasner CN, McMeekin DS, et al. A Phase II study of trabectedin single agent in patients with recurrent ovarian cancer previously treated with platinum-based regimens. Br J Cancer 2007;97:1618-24

78. Vergote I, Calvert $H$, et al. A randomised, double-blind, phase II study of two doses of pemetrexed in the treatment of platinum-resistant, epithelial ovarian or primary peritoneal cancer. Eur J Cancer 2009 Epub ahead of print]

79. Miller DS, Blessing JA, et al. A phase II evaluation of pemetrexed (LY231514, IND \#40061) in the treatment of recurrent or persistent platinum-resistant ovarian or primary peritoneal carcinoma: A study of the ynecologic Oncology Group. J Clin Oncol 2008;26 (Abstract 5524)

80. Friedlander M, Hancock KC, et al. Pazopanib (GW786034) is active in women with advanced epithelial ovarian, fallopian tube and peritoneal cancers: results of a phase II study. Ann Oncol 2008;19: viii211-viii216 (Abstract 6630)

81. Matulonis U, et al. Cediranib (AZD2171) is an active agent in recurrent epithelial ovarian cancer. J Clin Oncol 2008;26 (Abstract 5501) 